2014 EBOLA NEWSPAPER COVERAGE:

THROUGH THE LENS OF ORIENTALISM

A Thesis
presented to
the Faculty of the Graduate School
at the University of Missouri-Columbia
In Partial Fulfillment
of the Requirements for the Degree
Master of Arts
by
Dr. Earnest Perry, Thesis Supervisor
JULY 2017


(C) Copyright by Guimel Sibingo 2017

All Rights Reserved 
The undersigned, appointed by the Dean of the Graduate School, have examined the thesis entitled

\section{EBOLA NEWSPAPER COVERAGE: THROUGH THE LENS OF ORIENTALISM}

presented by Guimel Sibingo, a candidate for the degree of master of arts, and hereby certify that, in their opinion, it is worthy of acceptance.

Professor Earnest Perry

Professor Cristina Mislan

Professor Cynthia M. Frisby

Professor Tola Pearce 


\section{ACKNOWLEDGEMENTS}

I would like to thank my chair Earnest Perry for his help in guiding me through the thesis writing process and overseeing my work. I want to thank also committee member Cristina Mislan for helping me come up with this topic and for assisting me with how to approach critical discourse analysis. A big thank you to committee member Tola Pearce for providing expertise on postcolonial and African studies. Finally, I'd like to thank committee member Cynthia M. Frisby for her assistance in perfecting the organization and formatting of this study. 
TABLE OF CONTENTS

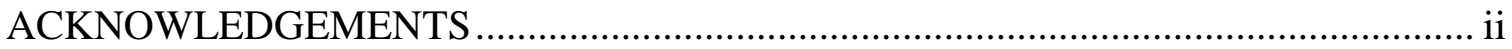

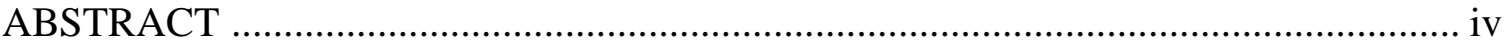

Chapter

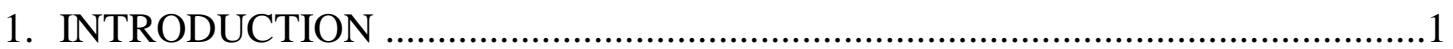

2. LITERATURE REVIEW \& THEORETICAL FRAMEWORK ................................4

Purpose of Study and Research Questions .......................................................19

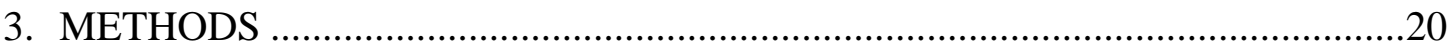

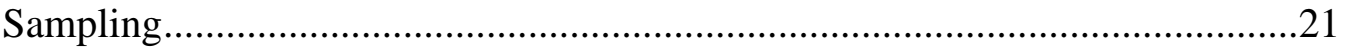

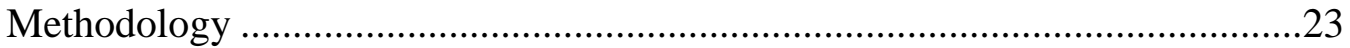

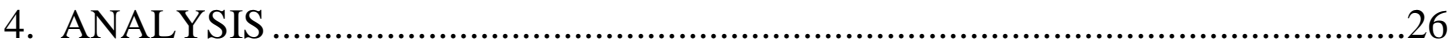

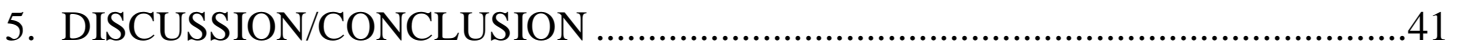

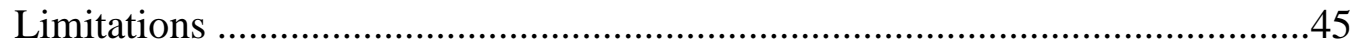

Recommendations for future research.............................................................

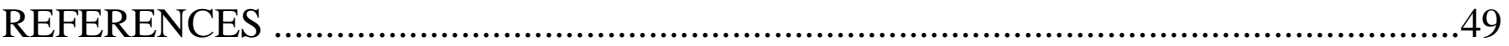


2014 EBOLA NEWSPAPER COVERAGE:

THROUGH THE LENS OF ORIENTALISM

\author{
Guimel Sibingo \\ Dr. Earnest Perry, Thesis Supervisor
}

\begin{abstract}
This study is a critical discourse analysis of United States (U.S.) newspaper coverage of the 2014 Ebola outbreak and its representation of West Africa in relation to the West. The study sought to determine whether the coverage reflected the theory of Orientalism, as defined by Palestinian-American philosopher Edward Said. Orientalism refers to the West's patronizing of Middle Eastern and Asian societies. Orientalism occurs when the West objectifies non-Western cultures turning them into an "other." In this study, the theory is applied to the West's patronizing of Africa.

The study analyzed 240 articles from The New York Times, The Washington Post, The Wall Street Journal, and The Los Angeles Times and determined that Orientalism is indeed reflected in the coverage, contributing to negative media portrayals of the continent of Africa. It also shows that as an institution of power, U.S. newspaper media contributes to the creation of a subject-object view of Africa in regards to the continent's relationship with the West.
\end{abstract}




\section{Chapter 1: Introduction}

To the dismay of many, the continent of Africa has long been synonymous with

death, disease, and tragedy. A victim of colonial powers, it has suffered the consequences of the West's exploitation and of its own internal corruption and conflict. Diseases like HIV/AIDS have, in the perspective of many, characterized the continent as diseased and broken. The 2014 Ebola outbreak in West Africa, unfortunately, did not do much to change that characterization.

As one of the worst epidemics since the first one in the 1970's, the outbreak began in 2013 in West Africa, with cases showing up in Guinea, Sierra Leone, Liberia, Nigeria and Senegal. The most affected countries (Liberia, Guinea, and Sierra Leone) were the most vulnerable economically and structurally. The 2014 outbreak killed more than 10,000 people, a little over 4700 from Liberia alone ("2014 Ebola Outbreak in West Africa - Case Counts," 2015).

When the World Health Organization first confirmed the outbreak in March 2014, there was limited coverage from media outlets in the United States. The epidemic exploded into American consciousness when Kent Brantley, an American medical doctor that had been providing relief in Liberia, became the first confirmed case in the United States after being flown back for treatment. A few months later, Liberian Thomas Eric Duncan died of the disease weeks after a visit to the United States to see his family. Duncan then infected two nurses. The public knowledge of these cases and two others of aid workers flown back for treatment caused widespread panic in the United States. 
Many say United States (U.S.) media made the situation worse through irresponsible coverage that perpetuated fear rather than providing important context and information. Although there had been years of studies and evidence available on Ebola and how infection spreads, hardly any of the facts seemed to make it into the television newscasts and magazines. Absent from some of the coverage also were the structural problems that contributed to Ebola's rapid spread, many of them rooted in colonial history. Instead, coverage focused on the cultural aspects that caused it to spread such as the way West Africans practiced burial.

There are many opinion pieces and even some research that has looked into the nature of newspaper Ebola coverage and its logistics, namely the number of articles published at any given time, what the content of the articles focused on, and any other factual content pertaining to textual analysis. However, not much has been said about the discourse in these articles and whether it reflects a given theory. Due to the lack of research that explores this coverage through a theoretical framework, there is a need to determine through a qualitative critical discourse analysis, whether Orientalism is reflected in 2014 Ebola newspaper coverage.

This study seeks to analyze United States newspaper coverage of the outbreak using the theory of Orientalism as defined by Palestinian-American philosopher Edward Said. Orientalism refers to the West's patronizing of Middle Eastern and Asian societies. It occurs when the West objectifies non-Western cultures turning them into an "other." In this study, the theory is applied to the West's patronizing of Africa. The study analyzed 
240 articles from The New York Times, The Washington Post, The Wall Street Journal, and The Los Angeles Times.

In addition to giving some background on the Ebola outbreak and its coverage, the literature review component of this study addresses the theoretical framework of Orientalism as defined by Said, epidemics and how they are covered in the media and media coverage of Africa. Following the literature review, the study discusses methodology and the process used to perform the critical discourse analysis. The study concludes with a discussion of the findings, the significance of the study, and the role it plays in the larger body of research. 


\section{Chapter 2: Literature Review \& Theoretical Framework}

In order to determine whether U.S. newspaper coverage of the 2014 Ebola outbreak reflects Orientalism, it is important to understand the literature of several issues within the topic, particularly the theory of Orientalism, coverage of epidemics in journalism and Africa in the media. Establishing what is known will provide a better understanding of the issues at hand.

\section{Orientalism}

Orientalism is a theory in postcolonial studies developed by Palestinian-American philosopher, Edward Said. Said defines Orientalism in two ways. The first is defined as the West's "patronizing" of Middle Eastern, North African, and Asian societies. The second is related to the concept of "othering." Orientalism in this case is "affiliated with the representation of the Self or Occident and the Other or Orient in which the Self is privileged and has upper hand to define, reconstruct the passive, silent and weak Other" (Moosavinia, Niazi, \& Ghaforian, 2011, p. 103). "Othering" also is the act of making pejorative distinctions or binarisms between two different societies (Mazrui, 2005).

The theory was first introduced in Said's book of the same name and addresses the ideological distinctions between Western and Eastern cultures (Said, 1979). According to the theory, the West, through its discourse and other means, has perpetuated a subject-object view of Oriental societies (Said, 1979). According to Said, the West sees the Orient as "exotic, intellectually retarded, emotionally sensual, governmentally 
despotic, culturally passive, and politically penetrable" (Mazrui, 2005, p. 69), dangerous, and a threat.

The theory is deeply rooted in colonialism. Orientalism emerges from colonialism's discourse of conquering and taming perceived dangerous and (Izadi \& Saghayer-Biria, 2007) uncivilized nations or societies (Jones \& Manda, 2006). That notion has birthed the idea of the Orient as inferior and created an Orient that according to Said is not real but merely exists in the imagination of the West (Said, 1979).

Orientalism primarily is employed through a lens of power and is used in order to control (Way, 2013). One of Said's main interests with orientalism is the relationship between those power structures and knowledge of the Orient, primarily employed, controlled, and invented by the West. Said believes that the knowledge imparted has a strong relationship with power and can be directly traced to colonialism and the West's efforts to control the Orient (Moosavinia, Niazi, \& Ghaforian, 2011).

For example, according to Said, the West has exercised that control through translating Eastern works into English as a way to dominate, subdue, and overtake (Said, 1979). On a societal level, Orientalism makes distinctions based on race, religion, and sexuality. Orientalist representations have been responsible for stereotypes and for clumping elements like race, nationality, and religion into one (Nurullah, 2010).

Said's theory of Orientalism has been employed extensively in communication research. Its most popular use in recent years is in the qualitative analysis of Middle Eastern or Muslim countries, individuals, or issues in the media. Much of the research seeks to determine the effect the changing political climate and the war on terror has had 
on Middle Eastern and Muslim issues and how much of that is reflected in the media's coverage.

The theory has been used to examine the portrayal of Saudi Arabia after 9/11 in British newspapers (al-Saud, 2009) where it was determined that islamophobia and racism seemed more acceptable in the coverage due to the sense of a an impending political threat. It has also been used to examine the portrayal of Saudi Arabian women in the American press versus portrayal of American women in the Saudi Arabian press, tying Orientalism with feminist critique (Mishra, 2007).

Further research has looked into the portrayal of face veils and its connection to nationalist and colonialist ideals in Canadian newspapers (Alrasheed, 2013), Iran's nuclear program in American newspaper editorials (Izadi \& Saghaye-Biria, 2007), Islamophobia in American cable news' coverage of the Ground Zero Mosque in New York (DeFoster, 2014), the othering of Muslim immigrant Americans that were once insiders but are now perceived as outsiders despite being American (Chuang \& Roemer, 2013), Western newspaper's representation of Sunni-Shia relations and framing them through the war on terror rather than through cultural context (Douai \& Lauricella, 2014), and portrayals of Muslim men and women as it relates to sex and marriage in a post $9 / 11$ world (Eltantawy, 2008).

Orientalism also has been used to study U.S. media's portrayal of Asian societies such as the New York Time's portrayal of China through an economic and consumerist lens (Ban, Sastry, \& Dulta, 2013) and the movie Slumdog Millionaire's representation of India (Mudambi, 2013). Other studies include the analysis of female representations of 
the body in the media (Augusto Klein \& Mazer, 2011), BBC's representation of Somali piracy (Way, 2013); the New York Time's and The Guardian's representation of Spain (Goss, 2004).

Orientalism and Postcolonial Studies. As mentioned before, orientalism is a postcolonialism theory. However, many scholars contest the term "post-colonial" because it gives a sense that colonialism is no longer in existence. In his article, "Coloniality and Modernity/Rationality" Anibal Quijano contends that although political colonialism no longer dominates world politics, coloniality, as he calls it, does. Coloniality is eurocentric domination of ideological, cultural, and social aspects of colonized cultures (2007).

Political colonialism created the world as we know it and perceive it today. Through colonialism the dichotomy of West versus non-West (with West perceived to be the subject in the subject-object relationship) was created. European powers seized world resources, dominated cultures and societies, in an effort to achieve that goal (Quijano, 2007).

Colonialism established several dichotomies many of them based on categories of race and ethnicity. One particular dichotomy is one of the developed nation versus the under-developed nation. The developed nation is assumed to be a universal standard with many colonized nations holding it up as an ideal. What is often not perceived is that the pursuit of 'development' can actually mean the pursuit of a Eurocentric ideal (Quijano, 2007). Quijano states that perceptions like these dominate the global landscape, making euro-centric coloniality one of the most common forms of domination. 
Quijano also sheds light on the concept of "othering" and the subject-object relationship between the West and the non-West. He states that in the subject-object relationship the 'subject', in this case the West, considers itself the original, credible entity and establishes its ideas and values as universal. The object, however, is deemed to be outside that norm and universality. Quijano states that in this subject-object relationship the West denies or is unaware of colonized countries' role in the creation of the West. Euro-centric thought assumes complete responsibility for modernity and rationality, but in failing to acknowledge how objectified cultures play a role in establishing what is perceived to be a European invention, it actually proves that the subject-object relationship does not in fact exist. This is very similar to Said's notion that the Orient is a creation of the West in the process of the West creating and conceptualizing itself (2007). Therefore, according to Said, Western ideals and values are not natural or universal but inventions.

Orientalism and African studies. Orientalism deals directly with Middle Eastern and Asian societal issues so it is no surprise that there has been very little research on how Orientalism might apply to Africa. Some of the main studies address portrayals of Somalia in Western media (Besteman, 1996). However, there have been a few African philosophers that have applied Said's theory to African studies, the most prominent of them being Valentin-Yves Mudimbe. His book The Invention of Africa (1988) is widely regarded to be as instrumental to African studies as Said's Orientalism (1979) was to postcolonial studies. 
Rather than using the language of "othering" Mudimbe instead chooses the word "alterity" (Mudimbe, 1988). He too considers Africa to be an invention of the West, however, that invention does not merely exist in the imagination of the West but is a selffulfilling prophecy (Mazrui, 2005). According to Mudimbe, Africa was reinvented five times, each time tied to its relationship with colonial powers such as North Africa and classical Mediterranean world, Africa and Semitic peoples, Islam's expansion in Africa, European colonization, and Africa's globalization.

Africa's conceptualization was highly influenced by Europe. European colonization brought with it the birth of "black consciousness" and the focus on skin color both for the good (strengthens African identity and pride) and for the bad (racism, inferiority, new wave of racism spread worldwide through slave trade). Even geographically, European colonization left its mark in African identity by "position[ing] the world so that we think of Europe as being above Africa rather than below in the cosmos" (Mazrui, 2005, p. 75).

Mudimbe and Said both agree that perceptions of non-Western nations are heavily tied to the history of colonization. Inevitably, such notions also can be reflected in media coverage of foreign nations.

\section{Africa in U.S. Media}

U.S. media coverage of international affairs has always been heavily unbalanced. Most international reporting, for example, carries a heavy national perspective (Nerone, 2011). This also is true of international reporting at large. Media portrayals of foreign 
countries tend to be heavily westernized, even in some Eastern countries like China (Ming, 2014).

International media coverage tends to lean towards certain global powers, as well, leaving others neglected. In a study measuring which countries are featured the most in news websites around the world, it was found that the United States was the most prominent country covered followed closely by the United Kingdom, France, Iran, Israel and Palestine (Segev \& Blondheim, 2013).

Such is the case with the continent of Africa. Studies show that Africa in many ways has been limitedly covered compared to other prominent regions. In one study, it was found that out of 3183 news stories in U.S. television in 1999, only 33 of them were about Africa (Golan, 2003). The few news stories about Africa tend to be mostly negative. The focus is centered on political unrest, foreign affairs, and diseases like AIDS/HIV.

In the United States, Africa is deemed newsworthy when there are major tragedies or when those tragedies pose a direct threat to the nation (Golan, 2008). However, when it is covered the focus is placed on health epidemics, famine, political conflict, genocidal activity, and acts of terrorism. This type of negative coverage is of concern because of the powerful effect media has on domestic perceptions of countries around the world.

Context: The West's role in Africa's poor infrastructure. Context and the lack thereof play an important part in determining whether Orientalism takes place in media coverage of Africa. Media outlets may choose to exclude certain contextual information in news articles, such as the role colonialism played in the spread of Ebola, and instead 
might attribute the disease's spread to the culture, inadvertently deeming that culture as inferior. Scholars often have considered it important to provide adequate context when covering epidemics that are tied to certain nations or peoples.

Part of that context is making known to the public the reasons why the countries most affected by the epidemic had such poor health infrastructures. In order to understand that, one needs to understand the effects that colonialism, development projects, and globalization has ha on the continent of Africa as a whole, as well as how Western institutions like the World Bank and the International Monetary Fund (IMF) - of which the United States was an integral part of creating - created the situations that have made it difficult for Africa to sustain social and economic stability.

The dichotomy of the developed versus the under-developed nation that is often used to compare Africa to the rest of the world, shows a lack of knowledge of the power structures not only behind the language of "development" and what that means, but also into the actual inequalities and struggles that Africans goes through. It also demonstrates a denial of how crucial the West was in creating that lack of "development."

Indeed, looking at the West's definition of development, Africa is very much behind. Out of the 34 countries that received low scores by the United Nations' Human Development Index in 2001, 30 of those were African nations. The index measures life expectancy, education and per capita income in countries around the world ("Human Development Index,” 2016). It makes sense that Africa's scores are low as health care infrastructures are poor, corruption is rampant, social and economic inequality is large, 
maternal and child mortality is high, life expectancy is low, and education is poor (Pearce, 2009).

The West has played an important role in creating such an Africa, starting with colonization. Since its inception, colonization has been couched under the guise of bringing civilization to an "uncivilized world." Although many believed this at the time, colonization was proved instead to be a tool of domination (Pearce, 2009).

Colonization was soon followed by the West's efforts to make sure Africa caught up to modern standards of development (Pearce, 2009). Newly freed governments from colonial powers sought to better their already debilitated economies and to secure the uncertain future of their nations. In order to do this, African nations had to once again turn to their former colonizers for financial assistance (McMichael, 2004).

In the 1940s, the United States led an effort to create international financial institutions with the goal of developing and sustaining the economies of formerly colonized nations. The organizations created, the World Bank and the IMF, became part of a deliberate attempt by the West to shape Third World nations for their own economic benefit, trapping them in relationships reminiscent of colonial times (McMichael, 2004).

They did this by lending money in the 1970s to Third World nations. The loans were given on the condition that Third World nations agree to certain trade agreements congruent with Western standards of development. These included a focus on industrialization particularly within agricultural sectors, deregulation of international trade by through the acceptance of First Nation imports and increase of raw material exports, less control over prices, devaluing of local currencies, less investment in the 
public sector, increased focus on capitalist and economic priorities, prioritizing scientific achievements, defining development as living standard betterment, and increasing Third World dependence to the developed world through military and aid programs shaped by Cold War-influenced intervention policies led by the United States (McMichael, 2004).

To be eligible for loans, nations were encouraged to focus their economies on raw material exports such as cocoa and oil, rather than on social institutions such as health and education. In return, First World nations transferred technological tools for raw material extraction. These all were used to sustain Western lifestyles (McMichael, 2004).

The policies forced Third World states to look outward for their development rather than inward, perpetuating the influence of colonial domination. Rather than spending money on health infrastructure and education, nations were conditioned to focus efforts on servicing the First Nation priorities mentioned above through loan requirements and the development "catch-up" process. The West chose to maintain control of formerly colonized nations by trying to define what civilization and development means. By imposing Western priorities and economic methods onto Third World nations they ended up enacting a form of economic violence (Pearce, 2009).

Development as defined by the West was said to be beneficial to Third World national interests when in fact, they were a means to maintain Western domination of its former colonies. Third World nations continued to provide raw agricultural exports to sustain Western lifestyles. The policies themselves proved to be detrimental, particularly in the agricultural sector as industrialization forced rural workers into the already overburdened cities, which in turn increased the cost of living (Pearce, 2009). 
The situation was made worse by the 1980 s debt crisis. Because loans were given out with relative ease in the 1970 s, a debt crisis ensued in the1980s and led to the implementation of tighter payback turnarounds, less loans given out and more restrictions on getting those loans. Third World nations had to borrow more in order to pay back their loans. This was especially hard on their economies. One solution to solve the problem was to decrease imports and increase exports. However, decreasing imports was not an option as African nations depended on First Nation imports. Increasing exports would not amount to much as the raw material prices decreased significantly due to material replacement (i.e. fructose corn syrup vs. sugar) (McMichael, 2004).

Countries had to then cutback even more on funding for public infrastructures like education and health, debilitating those even further. Poverty and violence naturally increased (Turshen, 2000). In regards to health systems, the cost increased, less money given to train health professionals decreasing the amount of health professionals available to service the population. With African nations in debt it became increasingly difficult to invest in institutions crucial to people's lives. Corruption within each nation and African leader's commitment to the development project exacerbated the problem (Pearce, 2009).

First World nations were quick to place the blame on Third World nations for the increasing in poverty in violence. They argued that if Third World nations had done a better job of following IMF and World Bank requirements, then they wouldn't be in the situation that they were in. This was made possible by the fact that certain nations had been able to meet those standards, dividing the Third World even further and decreasing equality among nations. What this did however, was remove the responsibility and divert 
attention from deliberate efforts by First Nations to preserve their elevated status by exploiting Third World nations and continents like Africa, effectively maintaining the colonial framework (McMichael, 2004).

There are signs, however, that perhaps some of these international financial institutions are taking some responsibility. In 2014, IMF declared that "wide income inequality can slow economic growth" and they proposed ways to reduce that inequality (Rugaberm, 2014). This seemingly presented a shift in how IMF approaches their policies towards the Third World, although that change is still to be seen.

As an institution of power, U.S. media rarely addresses these issues when covering Africa. This omission benefits Western institutions, evidence of how mass media and nationalism are tied together. The media plays a role in maintaining national identity by downplaying and sanitizing the United States' role in system injustices in the world (Yao \& Haggard, 2016). Media also is more likely to protect a nation's interest and is the main way through which citizens understand themselves and the world. If depictions of Africa in the media are then placed out of context, then that increases not only wrong perceptions but can have real consequences in people's lives as those perceptions lead to policies like the ones mentioned above that have real effect on the well-being of African people.

\section{Epidemics, Othering, and the Media}

Coverage of health epidemics has long been a characteristic of journalism from the Bubonic Plague to SARS epidemic in China (Wallis \& Nerlich, 2005). Coverage of epidemics in general, however, is mostly based on events, the amount of cases, and 
government involvement. The way the stories are developed tends to depend specifically on the nature of each disease covered (Shih, Wijaya, \& Brossard, 2008).

Epidemics have a powerful othering effect in society, making their coverage sensitive and important, as misplaced coverage can have a real effect on people's lives. Disease related-xenophobia historically has been a characteristic of journalism, particularly in media discourse about immigrants who often have been described as 'contagions' (Moore, n.d.) or 'pollutants (Cisneros, 2008). These types of depictions can contribute to harmful policies or even hate crimes against immigrants, showing the effects media can have on the lives of those they depict.

Since the current topic deals with a health epidemic in Africa, the coverage most notable to this study perhaps would be of HIV/AIDS, an epidemic that has been assailing Africa for a very long time and still has a stigma attached to it, particularly in South Africa (Goodall, Van der Riet, O'Neill, \& Killian, 2011). The disease often is regarded as a black disease and is wrongly attributed to race when the main reason why it assails most black South Africans is the socio-economic disparity - a direct result of past colonial oppression (Petros, Airhihenbuwa, Simbayi, Ramlagan, \& Brown, 2006).

HIV-positive individuals often are stigmatized, 'othered' and excluded. Because of the nature of the epidemic and the populations mostly associated with it, othering is deeply integrated with racial and ethnic biases (Petros, Airhihenbuwa, Simbayi, Ramlagan, \& Brown, 2006). The 'othering' as it relates to disease is often born out of fear and lack of understanding of the facts surrounding that disease. Medical professionals and organizations have pointed out that media coverage often fails to 
include important facts about a disease and how it spreads, choosing instead to focus on number of deaths or on government action (Basch, Basch, \& Redlener, 2014).

Many also have pointed out the lack of scientific information about a disease in the news (Ratzan \& Moritsugu, 2014). People use media coverage to help them understand complex issues, particularly of diseases they are not familiar with (Shih, Wijaya \& Brossard, 2008). Public health and media coverage often go hand in hand (Mwesiga, 2011) making responsible coverage of such issues even more important (Hooker \& Pols, 2006).

Ebola outbreak coverage. The 2014 Ebola outbreak was the largest and deadliest in its reach ("Ebola Virus Disease", 2014). Weak political and health infrastructures were a part of the problem with countries like Liberia and Sierra Leone having limited amount of health workers and slow response systems to epidemics. Important factors like these were omitted from some media coverage, focusing instead on the cultural aspects of why the disease spread, like African burial customs that involved touching the dead bodies. This type of exclusion of facts and lack of contextualization contributes to Orientalism.

Jared Jones describes this omission in his paper, "Ebola, Emerging: The

Limitations of Culturalist Discourse in Epidemiology" he writes,

Ebola has been exoticized, associated with "traditional" practices, local customs, and cultural "beliefs" and insinuated to be the result of African ignorance and backwardness. Indeed, reified culture is reconfigured into a "risk-factor." Accounts of the disease paint African culture as an obstacle to prevention and epidemic control efforts, at times even linking the eruption of the disease to practices such as burial traditions or consumption of bushmeat. But this emphasis is misleading; the assumption of African "otherness," rather than evidence, epidemiological or otherwise, underpins dominant culturalist logics that "beliefs" motivate behaviors, which increase the likelihood of Ebola's emergence and spread. Conspicuously absent from both popular and official rhetoric has been attention to larger structural determinants of the course of Ebola epidemics. Yet global forces condition the emergence of Ebola far more than culture does. Inequality and inadequate provision of 
healthcare, entrenched and exacerbated by a legacy of colonialism, superpower geopolitics, and developmental neoliberalism, are responsible for much of Ebola's spread (Jones, 2014).

To this date, studies on Ebola and media coverage also have been limited. Some have been done by health organizations that examined on what was emphasized in news coverage (death tolls versus how a disease spreads) (Basch, Basch, \& Redlener, 2014). The coverage of Ebola depends on a conceptual framework (Fifa, 2015). Ebola was covered differently when the concern was risk and crisis communication, security, or othering. Other studies also have examined how media moves from language of panic to language of containment in their coverage of Ebola (Ungar, 1998).

A particular study of Ebola coverage that addresses othering looks into an Ebola scare that took place in Canada when a Congolese woman visiting her family in Hamilton, Ontario was suspected of having disease. The media's coverage was sensational at first and created panic. The language surrounding the coverage turned to issues of immigration reform and "state control of racial bodies" (Murdocca, 2003, p. 24). It later was found that she did not have the disease, however, the media panic inevitably had an impact on Congolese immigrants in that town (Adeyanju, 2010). This shows how media coverage of epidemics can have real life consequences in people's lives.

Not much research has been done on coverage of Ebola in terms of how that coverage relates to a specific theoretical framework. This research aims to fill that gap by studying that coverage through the lens of Orientalism.

Africa has suffered in Western media representations. The nations often get clumped together into one, giving the perception that it is more like a country than a 
continent, one with thousands of different languages, ethnicities, and cultures. In a paper

presented at the Sixth Annual African Studies Consortium Workshop at the University of

Pennsylvania, Rod Chavis wrote this about Africa in Western media:

With the stroke of a journalist's pen, the African, her continent, and her descendants are pejoratively reduced to nothing: a bastion of disease, savagery, animism, pestilence, war, famine, despotism, primitivism, poverty, and ubiquitous images of children, flies in their food and faces, their stomachs distended. These "universal" but powerfully subliminal message units, beamed at global television audiences, connote something not good, perennially problematic unworthiness, deplorability, black, foreboding, loathing, sub humanity, etc. On the other hand, little is said about Africa's strategic importance to so called industrialized nations; her indispensability and relevance to world development, global technology, and the wealth of nations, derived from involuntary African largesse, are not acclaimed in the media (Chavis, 1998).

\section{Purpose of the Study \& Research Questions}

Given the issues discussed in the literature, I sought to analyze Ebola coverage through the lens of Orientalism, particularly to determine whether it has played into the perception of Africa as a diseased other. Orientalism has many nuances and has been used in many different ways throughout communication/media research. In my analysis, I gravitated towards the "othering" aspect of orientalism and how it relates to power structures reflected in the language of the articles.

In order to achieve this I will be approaching the subject with the following research questions:

RQ1: How did U.S. national newspapers cover the Ebola epidemic?

RQ2: Does the news coverage of the Ebola epidemic emphasize an Orientalist lens of West African countries?

RQ3: If so, how does this Orientalist discourse highlight the othering of West Africa? 


\section{Chapter 3: Methods}

Due to the critical cultural nature of the theoretical lens I used, I employed a critical discourse analysis approach to this study. I chose this method because, Orientalism is itself a critical cultural theory in that it also deals with power structures like language, organizations, entities and how they are used to dominate and control. This means the theory lends itself nicely to critical discourse analysis, particularly in the area of how the West seeks to dominate non-Western cultures politically, culturally, societally and economically.

\section{Critical discourse analysis}

Critical discourse analysis encompasses many levels of analysis two of which include the external relations of the text (social structures and the discourse governing the text), and internal relations of the text (grammar, vocabulary, etc.) (Fairclough, 2003). In its broader significance, critical discourse analysis is "fundamentally interested in analyzing opaque as well as transparent structural relationships of dominance, discrimination, power and control as manifested in language (Wodak, 2001)."

It looks into the relationship between language, knowledge, and power and how that is used to construct a type of reality or worldview. Its goal is to deconstruct the relationship between discourse and power structures in a particular text (Reitmanova, Gustafson, \& Ahmed, 2015). Those power structures can be dominant political, societal, or cultural ideas that suggest a certain type of reality. Critical discourse analysis critiques 
a reality portrayed in a text most often as it relates to issues common in critical theory such as race, gender, class, etc.

A critical discourse analysis allowed me to break down the discourse surrounding Ebola coverage as it relates to these elements of Orientalism. In addition, it allowed me to dig deeper on some of the specifics of how Africa is portrayed by Western media especially as it relates to disease and epidemics.

\section{Sampling}

The process for critical discourse analysis varies and differs from study to study. Based on readings of other studies that have employed the theory, process of analysis that I used involved choosing which newspapers to cover, creating an article sampling method that worked for my purposes, and using a coding method to analyze the articles.

The four national newspapers whose coverage I analyzed are The New York Times, The Washington Post, The Wall Street Journal and The Los Angeles Times. These four newspapers were picked because given the size of the news organizations and the large amount of resources, they were each able to offer extensive coverage of the outbreak. They also were picked because all newspapers had at least one reporter covering the story either directly from the affected region or from elsewhere in Africa.

All newspapers provided overall coverage of the epidemic from various perspectives: government, science, society and economics.

I analyzed news articles written by reporters and not editorials, opinion pieces, or wire service articles. I chose news articles and not editorials and opinion pieces because news articles reflect the news organization's main function of journalistic work in 
imparting information to an audience seemingly without a specific point of view. Content in a news article can be directly attributed to that news organization as editorials and opinion pieces (outside of copy editing and choice of whether to publish) do not necessarily reflect a news organization's views. Wire service articles are typically given by the Associated Press, a news organization not being studied in this research.

In order to choose the articles to analyze, I created a timeline of events of the Ebola outbreak, choosing three main time periods. The first period is when Kent Brantley first was brought into the United States and the last period is around the time the nurses that cared for Thomas Duncan were diagnosed with Ebola. The reason I picked this particular timeline is because the majority of articles on Ebola were published during this heightened period, a time where Americans were most aware of the outbreak. I matched that timeline with a list of news articles published in order from each of the four newspapers.

The five-month period of coverage produced a great number of news articles with nearly 4,000 articles coming from The New York Times alone, for that reason I sampled twenty articles from each newspaper published in three main time periods. This amounted to about 240 articles examined. How those articles were chosen depended on the time period. I did not analyze opinion pieces or wire service articles. Some time periods had some news events that illustrated public fear well and others did not (see below for sampling). Through this process, I attempted to create a bit of randomized selection process within the timeline.

The three time periods and sampling are as follows: 
- August 2-21, 2014: First case of Ebola confirmed in the United States. Dr. Kent Brantley is treated at Emory University Hospital in Atlanta (08/02) up until he was declared Ebola free (08/21). SAMPLING: In this time period there are only two main news event dates. For this one I sampled the first 10 articles from the start of the period and the last 10 articles towards the end of the period.

- September 30-October 8 2014: CDC announces that Liberian American Thomas Duncan has Ebola and is being treated at Texas Health Presbyterian Hospital in Dallas (9/30). Duncan dies (10/8). SAMPLING: In this time period there are only two main news event dates. For this one I sampled the first 10 articles from the start of the period and the last 10 articles towards the end of the period.

- October 12-24, 2014: CDC announces that two of Duncan's nurses, Nina Pham and Amber Vinson have the virus (10/12, 10/15). Both nurses are declared Ebola free (10/24). SAMPLING: In this time period there are three main news event dates. For this one I sampled the first 5 articles from each of the first two dates and the last 10 articles towards the end of the period.

\section{Methodology}

The analysis portion of the research was as follows: I first coded the articles based on source and date of publication. Then I looked into the content of each article searching for elements that stood out to me such as patterns, the use of language, framing, structure, etc. From there, I categorized quotes and took note of observations. 
Categories. I chose to organize articles under three categories: Africa, Disease, and Nation. Articles under Africa dealt mostly with direct coverage of events occurring in the most affected countries. In this category, the countries that received the most coverage were Sierra Leone and Liberia, given that they were the countries with the most deaths. I placed also under this category, articles that directly dealt with West African central characters such as West Africans living in the United States or West Africans from African communities in Dallas, the city where Thomas Duncan was staying with his family before his death. I chose this category because it is the main subject of this research.

The category Disease deals mostly with any articles that approach Ebola from a scientific perspective, namely how the disease spreads as well as any articles about vaccines in development. Under this category, I placed also any articles on foreign health workers that were infected and the concern that they would infect more. I picked Disease because, as mentioned in the literature review, a large amount of the research surrounding Ebola was on the medical information disseminated as well as the death toll.

The final category is Nation. Under this category I placed all articles that dealt with government agencies, hospitals, leaders, authorities or resources employed to fight the disease and to keep it from spreading. Most articles under this category deal with the World Health Organization, the CDC, United Nations, World Bank, President Obama, other U.S. politicians, and African governing authorities. Nation was picked as category to examine the power structures that managed the outbreak, all of them Western organizations of which the United States is heavily involved with. 
This category also fits in with critical discourse analysis as a form of studying examining power structures and language. United States media functions as a power structure as it has heavy nationalistic tendencies and affects how individuals perceive foreign nations that are covered. From these categories I pulled out themes and picked up on patterns. I then examined the relationship between the themes and the patterns and searched for links with the theory of orientalism. These will be explained in the analysis section. 


\section{Chapter 4: Analysis}

\section{Coverage}

The coverage from all four newspapers was fairly uniform with a few differences depending on the style of each newspaper. The news articles for the most part followed journalistic standards with leads, nut graphs, and information typically perceived to be newsworthy. All four newspapers equally covered major events and development in the outbreak, typical of what one would expect from journalistic endeavors. Events include:

- The arrival of Ken Brantly for treatment

- Thomas Duncan's diagnosis

- Duncan's death

- How the Dallas community where Duncan resided were reacting to the situation

- Stories on local West African community's reaction to the outbreak

- Nina Pham's, one of the nurses who cared for Duncan, diagnosis

- Backlash against CDC and Dallas hospital for how they dealt with the Duncan situation

- Extensive coverage on foreign health workers infected, including Craig Spencer a doctor working for Doctors Without Borders

- President Obama and other politician's statements and actions

- An article every time a person in the United States was suspected of having Ebola or admitted into a hospital out of suspicion of having Ebola 
- Several articles reported from Liberia and Sierra Leone about the outbreak

- Profiles of Africans fighting the disease

- Articles keeping track of the death toll

- Conflict that broke out after a slum near Monrovia, Liberia was quarantined

In terms of structure and topics, coverage of these events was fairly uniform with some differences. The New York Times displayed traditional and straightforward news writing style and choice of what to cover. The Wall Street Journal had more articles on the economic repercussions of the outbreak; The Washington Post had more articles on the CDC and government actions. The Post displayed also a more laid back writing style. The Los Angeles Times seemed to have more of an all-encompassing coverage of Africa.

\section{Themes}

Three main themes were present in the 2014 Ebola coverage: conflict, focus on Western issues and individuals, and the juxtaposition of the developed versus underdeveloped world.

Conflict. A notable theme that is very common to portrayals of Africa in general is a narrative of conflict. As is expected, the majority of the coverage around Ebola centered on conflict, tragedy, poverty, and violence. Instances of violence were found in the articles covering the clashes that erupted in a slum near Monrovia, Liberia, which resulted in many residents becoming injured after soldiers fired into crowds trying to leave the quarantined area. 
Another component of the conflict narrative was the focus on poor health infrastructure of the African nations, description of local hospitals and the sick, and the number of deaths. A focus on conflict is something fairly common in most journalism practice and does not seem to be an outstanding feature, however, due to the low number of positive stories on Africa, this proves to be problematic as it creates an othering effect.

The structure of news articles as a way to disseminate information in a more or less objective way contributed to an othering effect in that not much context was given for those facts. The instance of violence in Monrovia, Liberia is good example of how the poor infrastructures created in countries like Liberia by Western development projects and the debt crisis, give rise to chaotic situations of poverty and violence.

The article concerning that particular incident did not empathize with a community panicking due to such a deadly disease being in their midst. This is ironic given that the United States also went into a state of panic when Thomas Duncan died of Ebola in U.S. soil and infected two nurses, much of that exacerbated by irresponsible coverage, even though the chances of a United States citizen falling ill with Ebola were far less than for a West African. The lack of context concerning the poor health infrastructures has the same effect.

As previous research suggests, the majority of coverage on Africa focuses on conflict. Due to the nature of news articles and disseminating information without much context to historical reasons for that conflict, it is very easy to create a reality in which Africa as a continent is responsible for its own conflict and that the conflict is inherent to the continent as an entity. This is very similar to the narrative given by organizations like 
IMF and the World Bank and how they dealt with Africa and the Third World during debt crisis, blaming the Third World for not properly subscribing to their economic model. In other words, placing the blame on the oppressed rather than on the oppressor.

The United States media plays much of the same role as it is an institution of power. Critical discourse analysis examines the relationship between power and language in order to create a different reality. Language is the main tool employed by the United States media. In not providing enough context and focusing too much on conflict, U.S. national newspapers created a reality in which Africa is responsible for it's the origin and spread of Ebola and therefore morally culpable, dangerous, vile, and problematic. The act of creating that reality connects with Said's idea that the West defines the non-West as dangerous and despotic.

Focus on the West and western individuals. All four newspapers produced several articles straight from the affected areas namely Liberia and Sierra Leone. Some newspapers included features and profiles on locals and their struggle with losing family members to the disease. However, the majority of the articles, even the ones with Africa as a backdrop, focused on the West.

One of the ways in which that was accomplished was through the overwhelmingly greater focus on foreign health workers versus local health workers although there were some profiles that featured local health worker's efforts. Instances of foreign health worker deaths were given more isolated coverage while deaths of African health workers were buried in other articles. 
There were some exceptions to this rule. In a Los Angeles Times article titled "Health Workers in Liberia's Ebola outbreak often ostracized," the reporter bore witness to how African health workers often were ostracized upon returning to their families. The Washington Post did a profile on a faith healer and a local doctor both who came down with Ebola in their efforts to help their community but were eventually healed. The profile, written in a dynamic way, gave face to local health worker efforts. Another exception is the The Wall Street Journal article "Ebola Virus: For Want of Gloves, Doctor Dies" that addresses the shortage of materials in local hospitals and how local health workers were faced with the question of whether to keep treating patients without the proper equipment or risk dying themselves.

These articles however, were few and far between with the majority of the coverage focusing on health workers infected with Ebola that had to return to the United States or Europe for treatment as well as stories on how foreign aid workers were treating patients in Africa.

This focus is evidence of the West's prioritizing of itself and their own, creating a reality that the West is more important than other nations particularly Africa, consistent with critical discourse analysis and its explorations of how power and its relationship to language creates a particular reality. Nearly 10,000 Africans died during that time period and barely any stories focused on the families and the tragedy of their deaths, choosing instead to focus on Western individuals and Western organizations.

There also was a great emphasis on how the World Health Organization and the $\mathrm{CDC}$ were dealing with the disease. It is important to keep track of what governing 
organizations and how well they are doing, but because of the lack of sufficient coverage on actual Africans and African institutions (aside from some negative coverage of how African governments were dealing with the outbreak), this exacerbates the Westerncontrol of non-Western nations narrative. The West and its standards, like the health standards set by the CDC and WHO, are the norm and universal and when non-Western countries and regions like Africa do not follow those norms, they are in the wrong, the other.

The developed versus the undeveloped nation. A prominent pattern found throughout the coverage is lack of context for the apparent inadequacy of some African countries in containing the disease because presumably it is understood they do not measure up to developed countries' standards of development and modernity. This pattern manifested itself in articles about African government action, health infrastructures in Africa, as well as perceived cultural barriers to the containment of the disease.

There were several articles that highlighted the inadequacy of Liberia and Sierra Leonean governments in dealing with the outbreak. One article by The New York Times ("Lax Quarantine undercuts Ebola Fight in Africa Feature") describes police officers standing by while family members of an Ebola victim (now deceased), stepped freely in and out of a house that was supposed to be quarantined. A paragraph describes a woman's actions after she handled the body of a family member stricken with Ebola.

They had handled her body, putting them at serious risk of infection. But days after the death of Saudatu Koroma, her mother, Anna Conte, left to fill her plastic teapot from the communal water tap used by dozen of others. Her government minders seemed not to notice. 
Another paragraph in the article describes the poverty and lack of proper infrastructure of these countries to deal with the outbreak.

But the ability of countries at the bottom of global development rankings, with some of the world's weakest health systems, to enforce sweeping policies to contain such a virulent disease is a major concern. Only days after President Ellen Johnson Sirleaf of Liberia recommended cremating the bodies of Ebola victims, which are highly infectious, officials tried to bury dozens of corpses in a mass grave near where people lived, eliciting protests and subsequent complaints that some of the bodies were not properly covered with dirt.

To the naked eye it may seem that the article is simply reporting on what is being witnessed or what is happening and on one level it is. However, it is interesting what happens when the critical tone towards officials who have not complied with guidelines, is paired with uncontextualized cultural practices by Africans such as Anna Conte's handling of her daughter's body. Very little context is given as to why Conte is doing so. The criticism of officials mishandling frames her actions, creating a tone of slight judgment toward Conte's personal inability to comply with Western standards of disease fighting. This effect is achieved by not only blaming the officials but because of the lack of context she also is made personally and perhaps morally complicit in the spread of the disease.

The portrayal of Liberian and Sierra Leonean's response to the outbreak can be juxtaposed with articles about Nigeria's containment of the disease. Governing authorities in the United States and around the Western world, praised Nigeria's containment of the outbreak early on. Articles on Nigeria often compared its response to the poorer nations of Liberia and Sierra Leone. In the New York Times article "Nigeria's actions seem to contain Ebola outbreak", Nigeria ofen was described as being more developed through descriptions of better-equipped hospitals as well as rapid response to 
the finding and monitoring people who came into contact with the Ebola stricken individuals. The article includes an unchallenged quote by Tom Frieden, the CDC director on how Nigeria compares to other African nations.

"Nigeria's success shows how important preparation is, said Dr. Frieden, adding, "Some countries that could well be the next Lagos still don't have a clue about how to deal with this."

Comparisons of African nations with other African nations are not the only instances of this pattern. Comparisons between African nation's ability to deal with the disease and the United States, were made as well. Such is true of The Wall Street Journal's article "Ebola case in Dallas signals health system lapse." Other instances of comparison were subtler, this one however is much more explicit in its value judgments.

The deadliest Ebola outbreak in history is centered in the West African countries of Liberia, Sierra Leone and Guinea, though there is a separate outbreak in Congo. Unlike in West Africa, where the affected countries have fragile or barely existent health care systems, where people are being turned away from treatment centers, where family members are caring directly with those sick and dying from Ebola, the U.S. is far more equipped to isolate anyone with the virus and provide the highest level of care.

The way power and language are combined to create a different reality is in the juxtapositions and binaries created, where one side is deemed to be superior to the other. However, these are not just empirical statements, they carry with them an assumption that one (in this case Western ideals) has more value than the other.

The idea of the developed versus underdeveloped dichotomy is consistent with historical practices from Western institutions like IMF and the World Bank in attempting to redefine the Third World by Western economic standards, effectively imprisoning it in the same old colonial relationships even though the countries are no longer physically occupied by colonizing powers. To this day, Western institutions tied to Africa through 
aid programs and financial loans hold the continent hostage by demonizing it if it refuses to abide by Western ways. The United States media functions in similar ways, by comparing and juxtaposing "developed" (a Western invention) versus "underdeveloped" nations, it effectively places a moral judgment on that difference, deeming the West to be superior and more capable than the non-West. This creates an othering effect as described by Orientalism.

Previously I mentioned an instance where a cultural practice was deemed to be the reason why the disease spreads. This is common throughout many articles. There were many challenges in fighting the epidemic and different cultural norms were one of them. The consumption of bush meat from which the virus came, burial practices that involved heavy touching of the bodies, African's suspicion of health workers and seeking alternative healers instead, the fear of shaming in the community which led some to lie about whether their loved ones died from Ebola and the list goes on. These factors played into the spread of the disease, however, the coverage did little to separate culture from being valued as inferior because it did not conform to Western customs.

The Wall Street Journal article "Some Ebola-Stricken African Families Pay Bribes for Fake Death Records" addresses Liberian burial customs and the hesitation of some to reveal that their loved ones died of Ebola. The removed nature of the language, the framing and lack of context gives a sense that Liberian culture is inferior and that it is morally culpable for the spread of the disease.

Some of the teams sent to retrieve bodies of suspected Ebola victims here are collecting cash instead, allegedly accepting bribes to issue death certificates to families saying their loved ones died of other causes and leaving the body, locals and health workers say. 
Another excerpt suggests that Liberians would be placing the international community in danger if they fail to control their own corruption and "irresponsible" dealing with the disease.

It is a troubling development for an outbreak in which dead bodies are a major source of contagion and one that suggests local corruption could help undermine the international effort to contain the virus.

The only context given is a small paragraph loosely describing burial practices and adding a sentence about shame family members might feel. However, the article mostly frames the cultural practices according to how they measure up to Western ideals and as to whether they might pose a threat to the rest of the world.

The nature of news writing and the lack of context create a sense of removal from the reality of the situation. Information shared in news articles can the run the risk of simplifying a complex issue into one that can be easily digested. Often the way reporters figure this can be digested is to incorporate it through a Western lens, understandably so since that is the culture from which they come from.

The danger however, is that this practice creates an othering effect where the outside culture is being examined and valued by an "inside" culture. The narrative often unilateral and the same: African culture is flawed in that they do not conform with Western ways of perceiving disease, foreign involvement, how people relate to each other, etc. Very few times is an alternative narrative employed or explained in such a way as to bring understanding rather than judgment. Rarely does one get the idea that maybe there are different ways of looking at the world, that the Western worldview is not universal. 
Those instances are rare but they do exist. The Washington Post dedicated an entire article explaining and giving context to the consumption of bush meat in West Africa ("Why West Africans keep hunting and eating bush meat despite Ebola concerns"). It is one of few articles that directly address a cultural issue, providing enough context to create understanding.

"To the foreign eye, it looks like a flattened, blackened lump of unidentifiable animal parts. To many Africans, however, bush meat - the cooked, dried or smoked remains of a host of wild animals, from rats and bats to monkeys - is not only the food of their forefathers, it is life-sustaining protein where nutrition is scarce.

"Life is not easy here in the village," Guinean Sâa Fela Léno told the Guardian. Authorities and aid groups "want to ban our traditions that we have observed for generations. Animal husbandry is not widespread here because bush meat is easily available. Banning bush meat means a new way of life, which is unrealistic."

The article does not shy away, however, from talking about the dangers of eating bush meat when Ebola is a problem and the tendency of some to blame foreign health workers for the disease. Although a bit more context could be given, some careful language seems to be used.

In addition, uneducated villagers have sometimes been more inclined to blame the presence of medical teams for the spread of the virus, rather than bush meat or contact with sick friends or relatives.

The reporter ends the article making an important point.

"We don't want to exterminate bush meat, we just want to keep people from eating it," he continued.

Of course, that advice is easy to give from the relative comfort of the resource rich world

"If you're out in sub-Saharan Africa and you need food for your family, there aren't many options to get protein," Bausch said. 
The positive example above shows that is possible for the news media to do the best they can to provide context and a framework through which Western individuals can see Africa through. Although othering cannot be completely avoided, it can be diminished.

\section{Case Study: Thomas Duncan vs. others treated for Ebola on U.S. soil.}

Thomas Duncan was the first case of Ebola confirmed in the United States. The Liberian was visiting his son who was soon going to graduate from high school in Dallas. Shortly after his arrival he began to display symptoms. Upon visiting Texas Health Presbyterian, despite telling doctors that he had come from West Africa, he was sent home, as the information was not disseminated in the proper manner. It was only days after when he got home that he was admitted and diagnosed with the disease. After some time, he passed away. Panic ensued across the country and the coverage reflected that. There were more articles about the outbreak around that time, more articles on responses from politicians, and more scrutiny on the Texas hospital and the CDC. It was found out later, that Duncan had aided a neighbor infected with Ebola in Liberia by helping take her to the hospital.

Some of the coverage around Duncan turned him into a "dangerous man" who brought Ebola into the United States. This characterization was achieved through constant reporting on who he came into contact with, what the CDC was doing to contain the situation, dissatisfaction by the public at the CDC's handling of the case, and reporting on the two nurses that were infected after caring for him. Other articles that came out around that time referred to airline and airport screening procedures, how the local Dallas community was responding, and how the local schools responded seeing as 
Duncan came into contact with some children. It often felt like the tragedy of a human being dying of Ebola was lost to the excessive concern over whether he had infected any Americans. A Washington Post article, for example, "First Ebola patient in U.S. dies as officials amount new airport screening measures" framed Duncan's death around screening measures and keeping other from being infected by the disease.

Not all coverage of Duncan was objectifying, however, several profiles were written about him, some more humanizing than others. The Los Angeles Times published a touching profile, lauding him for helping his neighbor in a situation where not much else could have been done. The reporter portrayed Duncan as a man with dreams and aspirations. The reporter was also careful to pay homage to the young girl that he helped who eventually died.

If not for the Williams family's insistence, perhaps based on wishful thinking, that 19year-old Marthalene Williams didn't have Ebola, the disease might never have reached U.S. soil.

Duncan, 42, known to his neighbors as Eric, left home about 11 a.m. on Sept. 19 with a backpack and a suitcase, telling his neighbor, Irene Seyou, that he wasn't coming back for two years.

"He told me he was going to America. He said he was going to live his life and be there for two years, and then he will come home and build his own house," Seyou said.

Duncan helped carry her down a red sandy track, past his front door to her family's house. Together they placed her on the floor in her living room. She died there in the early hours of the next morning, surrounded by weeping members of her family.

"When she was dying, she was fighting," said a brother, Mekey, 18, who was in the room with all the family. "I felt so bad.... I knew she was going to die. My mother was crying. Every one of us was crying that night."

The Times also covered Duncan's memorial and included testimonies from community and family members.

Although overall coverage seemed to portray Duncan as a danger, there were some notable exceptions. Some of the coverage mentioned that family members were 
suspicious that Duncan did not receive the proper care because he was African. Other coverage explicitly delved in the question of whether Duncan's lack of early admission contributed to his death.

The Washington Post article "CDC Responds Rapidly to New York Ebola Case" asked this question of whether the hospital's treatment of Duncan had anything to do with his nationality.

Duncan's death brought difficult questions about why he died when other Ebola patients who have received care in the United States have, so far, survived.

The fact that he sought treatment at the hospital but initially was sent home remained a source of sadness and frustration. That lapse meant not only that Duncan could have exposed dozens of family members and others to the disease, but also that his prospects for recovery might have been diminished. As with many infectious diseases, the chances of survival increase the earlier medical care begins.

Some people close to Duncan alleged he was not properly treated because he was not American. "He is a Liberian man," Massa Lloyd, a close friend of Duncan's fiancee, said Wednesday. "The family feels he wasn't getting the right treatment because he was an African man. They feel America is fighting only for the white man, not the black man."

The Dallas hospital has insisted it treated Duncan as it would have any other patient.

Another exception is when The Wall Street Journal portrayed Duncan's death and Ebola not as something that is simply happening in Africa but that can happen anywhere in the world and that it does not matter what country you are from.

The Liberian man hospitalized in Dallas with Ebola died Wednesday, demonstrating the deadliness of the disease even in nations with advanced health-care systems, and the challenge of treating the virus when it isn't identified as early as possible ("Dallas Patient Dies")

The article questions why Duncan died and other survived. A paragraph on the CDC tracing the contacts is found much later in the story rather then at the beginning of other stories. Over all it addresses Ebola is a threat everywhere not just in Africa. This is different from the narrative by other articles that first world countries can easily keep it 
contained. It makes an explicit claim that Ebola doesn't choose which country; it is still deadly and dangerous. It takes away the culpability of Duncan as the reason Ebola reached U.S. from a moralistic perspective but rather makes a point that this is a world issue.

The question remains as to whether orientalism is reflected in Duncan's case. Whether or not he was treated differently by the coverage comes into question in that many of the infected health workers from the United States also were framed around contact-tracing, particularly Craig Spencer the doctor in New York who came under scrutiny for visiting a restaurant and riding the subway. However, there is a trend of treating the health workers as heroes and Duncan as the African who died. Although some articles asked the question of why did he die and not others, very few did so and the overall majority of the coverage seemed to turn him into an "other". This demonstrates how difficult it is to separate one's nationality and race from disease and how much little effort United States media put into exploring that relationship. 


\section{Chapter 5: Discussion/Conclusion}

The answer to the question of whether 2014 Ebola Coverage by national newspaper reflects orientalism is a complex one. Despite the complexity is apparent that Orientalism is indeed reflected in the 2014 newspaper coverage. Each newspaper provided varied forms of articles written by different reporters. Some were news articles, others features, still others news briefs. Some papers had stronger reporting on certain topics, others did not. Some articles displayed a more compassionate attitude towards African cultures, others did not. This answers the first research question regarding how newspapers covered the Ebola epidemic.

The second question of whether the coverage of the Ebola epidemic emphasized an Orientalist lens of West African countries is answered in the affirmative. The emphasis on conflict, focus on the West and western individuals, and the uncontextualized criticism of "underdeveloped" nations all contribute to the "othering" and objectification of Africa as an entity and force in the world. This type of othering continues the trend of poor representations of Africa in media and does not diverge from findings of the larger body of research on representations of Africa, discussed in the literature review. The third and final research question of how Orientalist discourse highlights the other of West Africa is answered in the connections between the aforementioned themes and Orientalism.

Another aspect that is in line with the United States media as a power structure that uses its influence to perpetuate a subject-object view of Africa is the role that 
parachute journalism plays in Africa's othering. The very act of a foreign journalist reporting on an African nation is a form of Western reconstruction of non-Western reality and experiences. During intense news cycles, national media outlets and newspapers tend to parachute into a location and get as many stories in as short time as possible. Once the news cycle ends, the journalists leave. Such type of parachute journalism leaves very little room for robust and complete reporting and can give rise to misrepresentations.

As outsiders, Western journalists are not always well-equipped to report on an entirely different culture and setting. Because Western media dominates the narrative of non-Western endeavors, this gives it immense power over how that reality is constructed and communicated. As an institution of power, it is then free to "define, reconstruct the passive, silent, weak other" (Mossavinia, Niazi \& Ghaforian, 2011, p. 103) in ways detrimental to that other.

\section{Conflict}

Journalism as a field tends to gravitate towards a focus on conflict, and this is true of most covered topics. Conflict, as discussed in the literature review, is one of the main ways Africa is characterized in foreign media. This proves to be especially problematic because of the disproportionate amount of negative versus positive stories of Africa in American journalism.

The focus on conflict can run the risk of painting Africa as a region that is always out of control and characterized by chaos. This ties with Said's notion that the West views the non-West as "governmentally despotic" (Mazrui 2005, p. 69). If a Westerner's exposure to Africa is solely based on what's covered in newspapers, it is likely he or she 
would assume that Africa is reduced to conflict, wars, famine, disease and the like. There is very little reporting on the continent's vibrant culture and its people.

\section{Focus on the West and Western Individuals}

The coverage reflected a disproportionate focus on the West and Western individuals. Doing so, re-tells and re-shapes the narrative around the continent creating an Africa that Said would most likely say is not entirely real. Because the newspapers control the narrative for a Western audience, they exercise power through story and language. This is in line with Said's notion that Orientalism is used through a lens of power and in order to control (Way, 2013).

The relationship between Orientalism, power structures and knowledge also is evident through the coverage. One of journalism's goals is to impart knowledge. If that knowledge or information creates a distorted reality and what Said describes as an invention, then it is a clear reflection of coloniality's influence on Western thought and ideals - ideals that seek to keep the West influential and powerful. Through the 2014 newspaper Ebola coverage and the disproportionate focus on African conflict in American journalism overall, the West maintains its dominance by establishing an invented narrative, perpetuating a reality that reasserts its own values as universal and Africa's values as outside of the norm. The focus on Western participation in fighting the outbreak also illustrates this point. A Western-centric narrative asserts the West's power to control and dominate. 


\section{The Developed vs. Undeveloped Nation}

The last theme is one that perhaps has the most robust connection with the theory. The coverage lacked context for the apparent inadequacy of certain African nations' ability to deal with the outbreak. That inadequacy was determined to be on the government level (relaxed quarantine enforcement measures) and cultural (burial traditions, suspicion against health workers). These were analyzed and examined from a Western perspective and judged by Western notions of modernity and development, reconstruction and redefining what Africa is in relation to Western values deemed to be universal.

Missing from the coverage was attributing part of the blame for the dire situation in West Africa to Western institutions and organizations that have sought to maintain colonial-type relationships to keep themselves in power and to benefit from African labor and suffering without much given in return. Criticism of Africa's handling of the outbreak was given without mention of how the power structure works, creating a reality where Africa is to solely to blame for their own demise. The United States media is itself an institution of power, by using language to perpetuate this reality it participates in Orientalist tendencies and practice.

Another problematic aspect of the coverage is the attribution of the spread of the disease to cultural practices, especially when done without proper context. This fits well within the Orientalist framework in that it paints Africa and African customs as "exotic, intellectually retarded, emotionally sensual, and culturally passive” (Mazrui 2005, p. 69). This particular aspect of the coverage places Western value of science and reason in 
direct juxtaposition with a culture whose worldview differs from the Western sciencecentric perspective. There is little acknowledgement of validity of another culture or a reach for understanding. Instead, the culture is perceived as exotic and dangerous.

In all its defining of African culture, the coverage failed to acknowledge the West's own role in the health infrastructure of the of the poorest nations affected, namely the development project of the 1970s and the debt crisis of the 80 s, deliberate initiatives by the IMF and World Bank that forced African nations into a globalized economic model focused on sustaining Western lifestyle rather than prioritizing pressing issues in African countries education and health.

In regards to health, this led to less training for health professionals, less medications, and a decline in quality for health institutions. By failing to acknowledge this, the coverage effectively denies how Africa contributes to the West's own selfconceptualization. Like Said would say, the Orient or non-Western entity is a Western invention. The coverage does not acknowledge there would be no concept of a West without Africa, no object without a subject.

\section{Limitations}

There were limitations to this study. My sampling system does not encompass United States newspaper coverage of Ebola in its entirety. Despite analyzing 240 articles from four different newspapers, the fact that I chose 20 articles out of the many published within each time period may have left out additional articles that serve as exceptions to my findings. If I were to go back and re-do this study with additional time, I would increase the sampling amount and analyze articles in a greater number. Another 
limitation is that I did not interview journalists or news organizations on their decision making and reporting process on these issues. Doing so might have given additional context to the content of the news articles. The final limitation is my bias towards Africa, as I am an African from Angola. My experiences a black African woman in the West might have influenced my findings, leading me to lean towards my conclusion that Orientalism is reflected in the coverage.

\section{Conclusion}

The purpose of this study was to see if Orientalism as defined by Edward Said is reflected in U.S. newspaper coverage of the 2014 Ebola Outbreak. The findings outlined in this thesis show that indeed it is reflected in the coverage. It's focus on conflict, Western subjects, and its subject-object treatment of African culture and infrastructure demonstrate an Orientalist view of Africa. My findings do not diverge from research on media portrayals of Africa, as discussed in the literature review. Like Orientalism professes, the coverage employs a lens of power used in order to control the narrative of the continent. Because alternative narratives of the continent are in short supply, Western media coverage holds the upper hand in defining, reconstructing, and inventing a subservient Africa according to its own standards.

From a journalistic point of view, the coverage of the 2014 Ebola Outbreak was complete, robust, and presented the necessary facts. The expected features and news articles were written. Government and leadership sources were sought out. Community members of the affected regions were interviewed. Journalists bore witness to what health organizations were doing to fight the outbreak. However, and unfortunately so, 
coverage of Africa continued to be one and the same with no alternative narratives

offered. It continues to be defined as a conflict-ridden continent, with exotic practices and cultural habits, intellectually inferior, and developmentally behind the West.

As an institution of power and influence, the United States media, through language, participates in perpetuating an Orientalist view of Africa and the redefined narrative of Africa as a subservient continent outside the norm of so-called Western "universal" values, both culturally and economically. Continuing down this path perpetuates these problematic perceptions that have the power to affect the lives of millions of Africans around the world. The employment of Orientalism not only gives rise to stereotypical ideas defined by distorted information, but also contributes to the continuation of harmful policies like ones employed by IMF and World Bank that influence African governments into diverting funds from important areas like health and education.

\section{Recommendations for future research}

Additional research can be done in ways to prevent an Orientalist approach to Africa in U.S. journalism. Qualitative studies using interviews from reporters looking into the process of their reporting might help determine how Western reporters approach Africa in their journalistic work. Additional research can be done on organizational processes, whether news organizations should invest in long-term Africa correspondence programs to generate more positive stories and avoid parachute reporting, or perhaps the employment of cultural sensitivity training sessions for reporters covering these issues. 
U.S. news media has an incredible amount of power and influence in how narratives about Africa are shaped and consumed in the West. As a participant in the system of Western institutions of power, that responsibility should be taken seriously and approached carefully and thoughtfully. Language and rhetoric are some of the most powerful tools that can be used in furthering Orientalism. This research and findings show that it is imperative Western news organizations became more cognizant of their role in the objectification of Africa in order to modify their coverage of the continent in a way that gives dignity and honor to it, decreasing its objectification. Perhaps then the West could begin to have a more Africa-centric glimpse into the continent. 


\section{References}

Adeyanju, C. T. (2010). Deadly fever: Racism, disease and a media panic. Black Point, N.S.: Fernwood Pub.

Alrasheed, G. (2013). The Face-Veil through the Gaze. Critical Approaches to Discourse Analysis across Disciplines, 7(1), 19-32.

al-Saud, B. S. (2009). Friend or Foe? Saudi Arabia in the British press post 9/11. Journal of Arab and Mulsim Media Research, 2(1-2), 39-51.

Augusto Klein, A.C..\& Mazer, D. (2011). Corpus absconditum; imagens do Oriente e ideologia na representação do corpo feminino na imprensa. (Portuguese). Revista FAMECAOS - Midia, Cultura, E Tecnologia, 18)3, 700-716.

Ban, Z., Sastry, S., \& Dutta, M. (2013). "Shoppers' Republic of China": Orientalism in Neoliberal U.S. News Discourse. Journal of International and Intercultural Communication, 6(4), 280-297.

Basch, C. H., Basch, C. E., \& Redlener, I. (2014). Coverage of the Ebola Virus Disease Epidemic in three widely circulated United Sates newspapers: Implications for preparedness and prevention. Health Promotion Perspectives, 4(2), 247-251.

Besteman, C. (1996). Violence and "othering" Somalia. Cultural Anthropology, 11(1), 120-133.

2014 Ebola Outbreak in West Africa - case counts. (2015, February 10). Retrieved May 10, 2015, from http://www.cdc.gov/vhf/ebola/outbreaks/2014-west-africa/casecounts.html 
Chavis, R. (1998). Africa in the Western Media. Retrieved May 10, 2015, from http://www.africa.upenn.edu/Workshop/chavis98.html

Chuang, A., \& Roemer, R. C. (2013). The immigrant muslim american at the boundary of insider and outsider: Representations of faisal shahzad as "homegrown" terrorist. Journalism \& Mass Communication Quarterly, 90(1), 89-107.

Cisneros, J. D. (2008). Contaminated communities: The metaphor of "immigrant as pollutant" in media representations of immigration. Rhetoric \& Public Affairs, 11(4), 569-602.

DeFoster, R. (2014). Orientalism for a new millenium: Cable news and the specter of the ground zero mosque. Journal of Communication Inquiry, 39(1), 63-81.

Douai, A., \& Lauricella, S. (2014). The terrorism frame in neo-orientalism: Western news and the Sunni-Shia Muslim sectarian relations after 9/11. International Journal of Media \& Cultural Politics, 10(1), 7-24.

Ebola virus disease. (2014). Retrieved from

http://www.who.int/mediacentre/factsheets/fs103/en/

Eltantawy, N. (2008). Gender Misrepresentation, Islamophobia \& the Western Press: Hypersexuality, Harems \& Sex Slaves. Conference Papers - National Communication Association. 1.

Fairclough, N. (2003). Analyzing discourse: Textual analysis for social research. London: Routledge. 
Fifa, G. (2015). Ebola (EVD) through the lenses of news articles (Unpublished master's thesis). Linneuniversitetet.

Golan, G. (2003) 'America's Narrow Window to the World: An Analysis of Network Global Coverage’, International Communication Bulletin 38(3-4): 2-11.

Golan, G. J. (2008). Where in the world is Africa: Predicting coverage of africa by US television networks. The International Communication Gazette, 70(1), 41-57. doi:10.1177/1748048507084577

Goodall, J., Van der Riet, M., O'Neill, V., \& Killian, B. (2011). HIV and AIDS related stigma: A necessary protective mechanism for children in high exposure areas? South African Journal of Psychology, 41(2), 187-195.

Goss, B. M. (2004). Foreign Correspondent: Spain in the gaze of The New York Times and The Guardian. Journalism Studies, 5(2), 203-219.

Hooker, C., \& Pols, H. (2006). Health, Medicine, and the Media. Health and History, 8(2), 1-13. Retrieved October 13, 2015, from http://www.jstor.org/stable/40111540

Human Development Index. (2016). Retrieved December 05, 2016, from https://en.wikipedia.org/wiki/Human_Development_Index

Izadi, F., \& Saghaye-Biria, H. (2007). A discourse analysis of elite American newspaper editorials. Journal of Communication Inquiry, 31(2), 140-165.

Jones, J. (2014). Ebola, Emerging: The Limitations of Culturalist Discourses in Epidemiology. The Journal of Global Health. Retrieved May 10, 2015, from http://www.ghjournal.org/ebola-emerging-the-limitations-of-culturalistdiscourses-in-epidemiology/ 
Jones, A., \& Manda, D. L. (2006). Violence and 'othering' in colonial and postcolonial africa.

Case Study: Banda's Malawi. Journal of African Cultural Studies, 18(2), 197-213.

Martinot, Steve (2007) "The Dual-State Character of U.S. Coloniality: Notes Toward Decolonization," Human Architecture: Journal of the Sociology of SelfKnowledge: Vol. 5: Iss. 3, Article 34.

Mazrui, A. A. (2005). The Re-invention of Africa: Edward Said, V.Y. Mudimbe, and beyond. Research in African Literatures, 36(3), 68-82.

McMichael, P. (2004). Development and social change: A global perspective. Los Angeles: SAGE.

Ming, D. (2014). Does the medium make a difference? A comparative analysis of international news in Chinese online and print newspapers. China Media Research, 10 (2), 35-47.

Mishra, S. (2007). "Liberation" vs "Purity": Representations of Saudi Women in the American Press and American Women in the Saudi Press. The Howard Journal of Communications, 18, 259-276.

Moore, H. (n.d.). Contagion from abroad: U.S. newspaper framings of immigrants and epidemics, 1891 to 1893. The Atlanta Review of Journalism History, 32-89.

Moosavinia, S., Niazi, N., \& Ghaforian, A. (2011). Edward Said's Orientalism and the Study of the Self and the Other in Orwell's Burmese Days.Studies in Literature and Language, 2(1), 103-113. Retrieved December 3, 2015. 
Mudambi, A. (2013). Another Look At Orientalism: (An) Othering in Slumdog Millionaire. Howard Journal of Communications, 24(3), 275-292. doi: 10. 1080/10646175.2013.805990.

Mudimbe, V. Y. (1988). The invention of Africa: Gnosis, philosophy, and the order of knowledge. Bloomington: Indiana University Press.

Murdocca, C. (2003). When Ebola Came to Canada: Race and the making of the respectable body. Atlantis, 27.2, 24-31.

Mwesiga, A. (2011). Reporting epidemics: Newspapers, information dissemination and the story of Ebola in the Ugandan district of Luweero. PanAfrican Medical Journal, 9(43), 1.

Nerone, J. (2011) Does Journalism History Matter?, American Journalism, 28:4, 7-27

Nurullah, A. S. (2010). Portrayals of Muslims in the media: "24" and the 'Othering' process. International Journal of Human Sciences, 7(1), 1021-1045.

Pearce, T. O. (2009). Globalization and the Cycle of Violence in Africa (S. K. Cha-Jua \& H. A. Neville, Eds.). In T. Koditschek (Ed.), Race Struggles (pp. 80-84). Chicago, IL: University of Illinois Press.

Petros, G., Airhihenbuwa, C. O., Simbayi, L., Ramlagan, S., \& Brown, B. (2006). HIV/AIDS and 'othering' in South Africa: The blame goes on. Culture, Health, \& Sexuality, 8(1), 67-77.

Quijano, Anibal (2007) Colonialisty and Modernity/Rationality, Cultural Studies, 21:2-3, $168-178$ 
Ratzan, S. C., \& Moritsugu, K. P. (2014). Ebola Crisis - communication chaos we can avoid. Journal of Health Communication, 19(11), 1213-1215.

Reitmanova, S., Gustafson, D. L., \& Ahmed, R. (2015). "Immigrants Can Be Deadly": Critical Discourse Analysis of Racialization of Immigrant Health in the Canadian Press and Public Health Policies. Canadian Journal Of Communication, 40(3), 471-487.

Rugaber, C. S. (2014, March 13). IMF warns income disparities can hurt economies. St. Louis Post Dispatch. Retrieved September 05, 2016, from http://www.stltoday.com/business/local/imf-warns-income-disparities-can-hurteconomies/article_a869ea5b-8576-5081-b1fd-b307d25976bb.html

Said, E. W. (1979). Orientalism. New York: Vintage Books.

Segev, E. \& Blondheim, M. (2013). America's Global Standing According to Popular News Sites From Around the World. Political Comunication, 30 (1), 139-161. doi:10.1080/10584609.2012.737418

Shih, T., Wijaya, R., \& Brossard, D. (2008). Media coverage of public health epidemics: Linking Framing and Issue Attention Cycle toward an integrated theory of print news coverage of epidemics. Mass Communication \& Society, 11, 141-160. doi:10.1080/15205430701668121

Turshen, M. (2000). African women's health. Trenton, NJ: Africa World Press.

Ungar, S. (1998). Hot Crises and Media Reassurance: A comparison of emerging diseases and ebola zaire. The British Journal of Sociology, 49(1), 36-56. Retrieved October 13, 2015, from http://www.jstor.org/stable/591262 
Wallis, P., \& Nerlich, B. (2005). Disease metaphors in new epidemics: The UK media framing of the 2003 SARS epidemic. Social Science \& Medicine, 60, 2629-2639.

Way, L. C. (2013). Orientalism in online news: BBC stories of Somali piracy. Journal of African Media Studies, 5(1), 19-33. doi:10.1386/jams.5.1.19_1

Wodak, R., \& Meyer, M. (Eds.)(2001). Methods of critical discourse analysis. London: Sage Publications.

Yao, Q. J., \& Haggard, C. (2016). The Mediated Communities: Testing Media Effects on the Construction of National Identity, National Pride, and Global Identity in China, Brazil, India, South Africa, and the US. China Media Research, 12(3), 8998. 